Journal of Agricultural Sciences
(Tarim Bilimleri Dergisi)

\title{
Carbon Storage Potential and its Distributions in the Particle Size Fractions in Harran Plain, Turkey
}

\author{
İbrahim Halil YANARDA $\breve{G}^{\mathrm{a} *}(\mathbb{D})$, Asuman BÜYÜKKILIÇ YANARDAĞ $\breve{G}^{\mathrm{a}}\left(\mathbb{D}\right.$, Ahmet R. MERMUT $^{\mathrm{b}, \mathrm{c}} \mathbb{C D}^{\mathbb{D}}$, \\ Ángel FAZ CANO ${ }^{d}$ iD

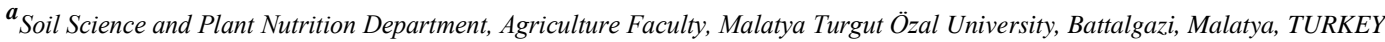

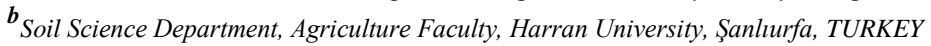 \\ ${ }^{c}$ Department of Soil Science, University of Saskatchewan, Saskatoon, Saskatchewan, CANADA

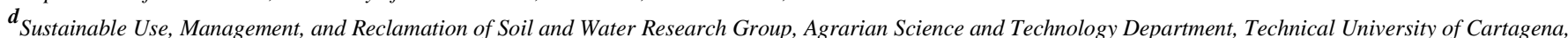 \\ Cartagena, Murcia, SPAIN
}

ARTICLE INFO

Research Article

Corresponding Author: İbrahim Halil YANARDAĞ, E-mail: ibrahim.yanardag@ozal.edu.tr

Received: 1 April 2021 / Revised: 8 October 2021 / Accepted: 9 October 2021 / Online: 01 September 2022

Cite this article

YANARDAĞ i H, BÜYÜKKILIÇ YANARDAĞ A, MERMUT A R, FAZ CANO A (2022). Carbon Storage Potential and its Distributions in the Particle Size Fractions in Harran Plain, Turkey. Journal of Agricultural Sciences (Tarim Bilimleri Dergisi), 28(3):501-510. DOI: 10.15832/ankutbd.907173

\section{ABSTRACT}

In recent years, there has been increasing international interest in increasing and sustainably managing soil $\mathrm{C}$ stocks to contribute to combating climate change and support food security. In this context, determining the $\mathrm{C}$ storage capacity of soils and examining the distribution of soil $\mathrm{C}$ based on fractions is of great importance for a better understanding of $\mathrm{C}$ dynamics. The present study investigated the storage potential of soil organic carbon (SOC), inorganic carbon (SIC) and total carbon (TC) in 16 selected profiles, and SOC and SIC distribution in five different particle size fractions (2000-425 $\mu \mathrm{m}, 425-150 \mu \mathrm{m}, 150-106 \mu \mathrm{m}$, $106-75 \mu \mathrm{m},<75 \mu \mathrm{m})$ of the Harran plain in Turkey. The results revealed that the particle size distribution in the surface layer varied in the following order depending on soil weight: 850-250>2000-850> 250$150>150-75>75 \mu \mathrm{m}$. The organic $\mathrm{C}$ content of the soils is low due to the semi-arid climate conditions. Fraction-based soil SOC distribution was in the following order: $11 \%$ at $2000-850 \mu \mathrm{m}, 15 \%$ at $850-250 \mu \mathrm{m}, 21 \%$ at $250-150 \mu \mathrm{m}, 23 \%$ at $150-75 \mu \mathrm{m}$ and $<75 \mu \mathrm{m} 30 \%$. Organic matter fractions differed according to the particle size distribution and the applicable soil management system. Stable organic matter content was significantly related to clay content and greatly influenced by the type of soil management used.

Keywords: Soil organic carbon, Soil inorganic carbon, Carbon storage, Particle size, Harran plain

\section{Introduction}

Soil carbon $(\mathrm{C})$ is the largest terrestrial carbon reserve and contains about $1.5 \mathrm{Eg}\left(\right.$ ie $1.5 \times 10^{18} \mathrm{~g}$ ) of carbon, of which $0.68 \mathrm{Eg}$ is organic carbon (Zhang et al. 2020). Soil organic matter (SOM) positively affects the physical, chemical and biological properties of the soil (Sakin \& Yanardağ 2019). It is also one of the most important components in the soil due to its capacity to affect plant growth and yield (Bongiovanni \& Labartini 2006). In C stabilization processes, the structure of organic compounds in SOM, their true resistance to weathering and their interactions with the soil mineral fraction are closely related (Marinari et al. 2010). The new origin of SOM is closely related to biological activity in the soil, while new and middle-aged organic matter can contribute to the improvement of the physical structure of the soil (Wander 2004). However, different soil types may also react differently to the stabilization and sequestration of C (Yanardağ et al. 2015).

Measuring the potential of agricultural soils to soil organic carbon (SOC) dynamics will help evaluate the contribution of cultivated soils to the global $\mathrm{C}$ balance as a carbon source or sink. However, there are many uncertainties about the impact of SOC dynamics on the soil system (Mermut et al. 2000; Li 2002), and the ultimate potential for C stabilization in soils is unknown (Smith 2004). The quality of SOM depends on its distribution between unstable and stable organic components. Stable organic compounds in the soil include humus materials and other macromolecules or are physically preserved by their adsorption on mineral surfaces or bound in aggregates (Tobiasova et al. 2012). One of the key elements to reliably evaluate SOM dynamics is the experimental identification of SOM pools associated with stabilization mechanisms (Abdul Kader 2006).

Soil organic matter can be analyzed based on different fractions and basic information about the processes and products of soil formation can be provided by soil particle size distributions (Gunal et al. 2011). Interactions of physical, chemical and biological processes in the soil affect aggregate formation and stabilization (Kocyigit \& Demirci 2010). These materials with a 
particle size of $<2 \mu \mathrm{m}$, mostly silt and clay, have slow cycle times and stabilize in the primary organo-mineral structure by interacting mainly with minerals (Chenu \& Plante 2006). Here, the clay-sized OM usually accounts for more than 50\% of the SOM, and the sum of clay and silt $(<20 \mu \mathrm{m})$ can be over $90 \%$ (Christensen 1996). In addition, changes in organic matter levels caused by land use can be better understood by determining the distribution of fractions (Figueiredo et al. 2010). Dalal \& Mayer (1986) reported that the change of some soil properties depends on which fractions of SOM are accumulated rather than the total amount of SOM.

The objectives of this study are (1) to determine the soil organic carbon, inorganic carbon, and total carbon storage potential of the Harran plain in 16 selected profiles, and (2) to determine the SOC and SIC distribution in five different particle size fractions $(2000-425 \mu \mathrm{m}, 425-150 \mu \mathrm{m}, 150-106 \mu \mathrm{m}, 106-75 \mu \mathrm{m},<75 \mu \mathrm{m})$.

\section{Material and Methods}

\subsection{Description of the study area}

Harran Plain is located in the south-eastern part of Şanlıurfa province, Turkey, which is in the center of Turkey's major irrigation and development project (Southeastern Anatolian Project, GAP). It lies between the longitudes of $38^{\circ} 39^{\prime}-39^{\circ} 30^{\prime}$ E and the latitudes of $36^{\circ} 43^{\prime}-37^{\circ} 11^{\prime} \mathrm{N}$ and spans an area of 225000 ha.

The elevation ranges between 350 and $450 \mathrm{~m}$ a.s.l. and it increases from the south to the north. The plain has a semi-arid climate with limited precipitation between June and September. The long-term mean annual temperature is about $18{ }^{\circ} \mathrm{C}$, the highest annual mean temperature is $31.4{ }^{\circ} \mathrm{C}$ in July, and the lowest annual mean temperature is $5.8{ }^{\circ} \mathrm{C}$ in January. The annual mean relative humidity and precipitation are $57 \%$ and $284.2 \mathrm{~mm}$, relatively (Yesilnacar \& Güllüoğlu 2007). The dominant crops in the area are cotton, corn, and wheat.

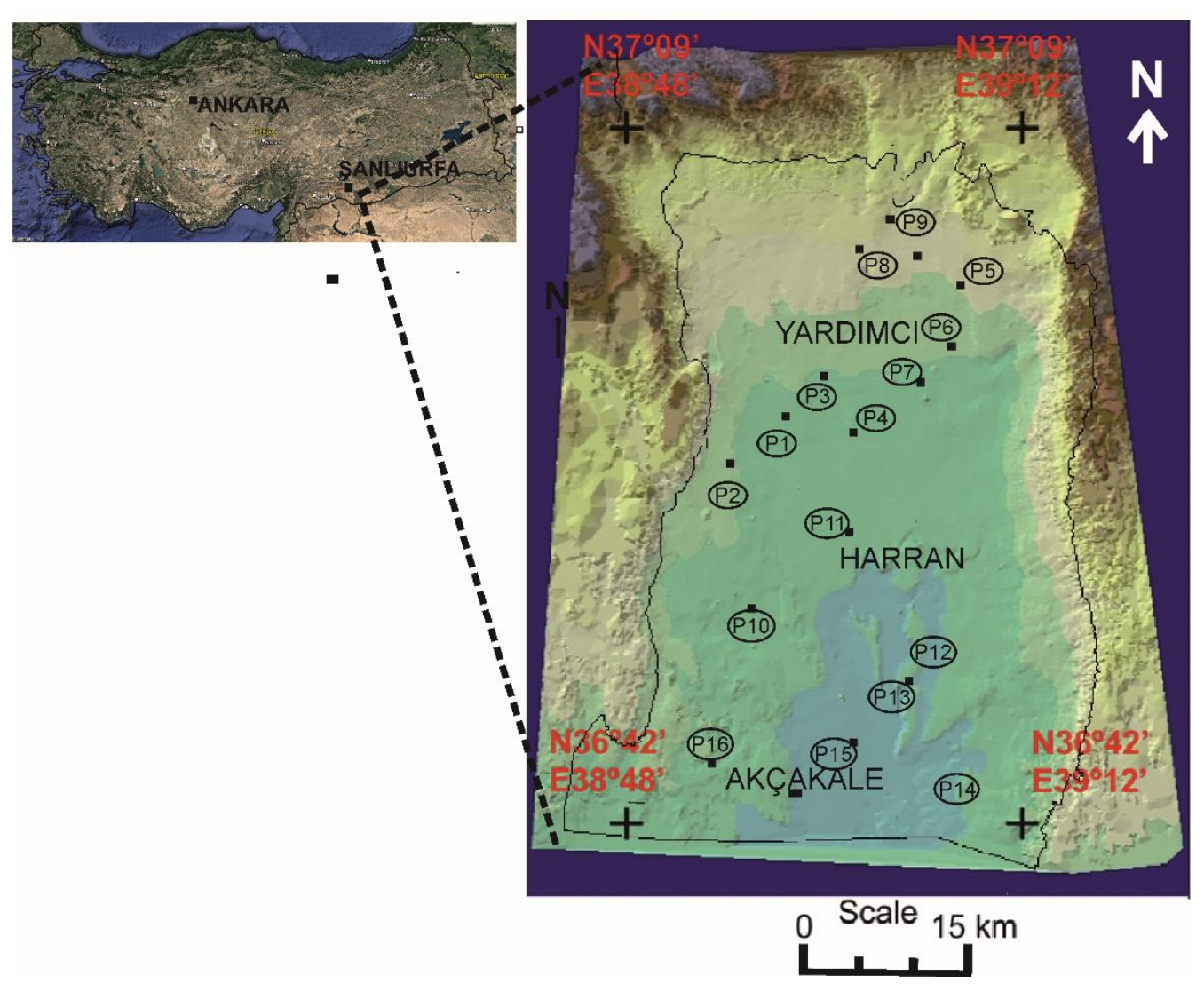

Figure 1- Distribution of 16 selected soil profiles in the studied area

Soil samples were taken from 16 series of genetic horizons in 3 replications in wheat fields in Harran Plain. In the study, soil profiles differ between $1.4 \mathrm{~m}$ and $3.6 \mathrm{~m}$ were dug up until reaching the main material. The distribution of 16 selected soil profiles $(\mathrm{P})$ in the studied area is presented in Figure 1. The soil locations and taxonomies are K1sas 1 (P1) (36 $\left.58^{\prime} 00.3^{\prime \prime} \mathrm{N}, 38^{\circ} 55^{\prime} 42.3^{\prime \prime} \mathrm{E}\right)$; Typic Torrert, Çekçek (P2) (3656'49.9"N, 38 54'05.8"E); Typic Torrifluvent, Harran 1 (P3) (3700.0'06.2"N, 3858'57.3"E); Vertic Camborthid, Kisas 2 (P4) (3658 '05.6"N, 3901'09.5"E); Typic Torrert, Bellitaş (P5) (3701'09.6 "N, 3909'13.2"E); Typic Torrifluvent, Gürgelen 1 (P6) $\left(37^{\circ} 00^{\prime} 0.504^{\prime \prime} \mathrm{N}, 39^{\circ} 09^{\prime} 0.632^{\prime \prime}\right)$; Typic Calciorthid, İkizce (P7) (37 $01^{\prime} 0.501^{\prime \prime} \mathrm{N}$, $\left.39^{\circ} 07^{\prime} 0.299^{\prime \prime E}\right)$; Vertic Torrifluvent, Sirrın (P8) (3705'0.461"N, 3902'0.144"E); Vertic Camborthid, İrice (P9) (3706'0.062" N, 
3903'0.766"E); Typic Calciorthid, Beğdeş (P10) (3650'0.491"N, 3854'0.169"e); Typic Torrert, Harran 2 (P11)

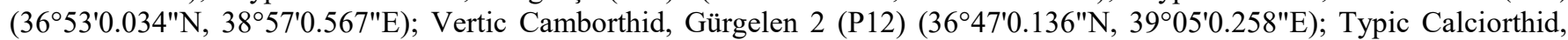

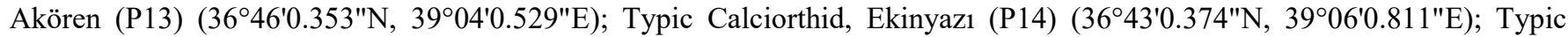
Calciorthid, Akçakale (P15) (36 $\left.{ }^{\circ} 45^{\prime} 0.370^{\prime \prime} \mathrm{N}, 39^{\circ} 58^{\prime} 0.538^{\prime \prime} \mathrm{E}\right)$; Typic Torrert, Gürgelen 3 (P16) (36 $\left.44^{\prime} 0.370^{\prime \prime} \mathrm{N}, 38^{\circ} 52^{\prime} 0.343^{\prime \prime}\right)$; Typic Calciorthid. The soils of the plain are clayey with a slightly alkaline $\mathrm{pH}\left(\mathrm{pH}_{\mathrm{H} 2 \mathrm{O}} 7.5-8.0\right)$. The minimum permeability values of the soils are between 0.22 and $3.51 \mathrm{~m} \mathrm{day}^{-1}$ (GDSHW 2003). The majority of soils in the plain are classified as Vertisol according to Soil Survey Staff (2006). The dominant silicate clay minerals are smectite, and palygorskite, however, illite and kaolinite are also found in the mixture. The soils are generally well developed with ABC horizons and although lime content is high, soil organic matter is usually around 1.0\% (GDSHW 2003).

The selected physical-chemical soil characteristics were given in Table I. The soil textures were generally clayey and the amount of clay tended to increase towards the center of the study region. The southern sample sites had higher salinity (15.62 $\mathrm{dS} \mathrm{m}^{-1}$ ). Due to excessive and uncontrolled irrigation and fertilization, in addition to poor natural drainage, soil salinity was very high. The soils were alkaline and the $\mathrm{pH}$ was ranged between 7.37 and 8.40 (Table 1).

The studied area had high carbonate contents (mean 26.60\%). The organic matter concentrations were between 0.87 and $2.12 \%$. The studied area had high amount of clay, which were ranged between 30 and $60 \%$. The dominant silicate clay minerals were smectite therefore, cation exchange capacities were high and ranged between 28.61 and $48.12 \mathrm{cmol}^{+} \mathrm{kg}^{-1}$. The bulk density of 16 studied soil profiles was changed between 1.25 and $1.35 \mathrm{~g} \mathrm{~cm}^{-3}$ (Table I).

Table 1- Selected physical-chemical characteristics of the soil study

\begin{tabular}{|c|c|c|c|c|c|c|}
\hline $\mathrm{SP}^{*}$ & $p H$ & $\begin{array}{c}E C \\
d S m^{-1}\end{array}$ & $\begin{array}{c}O M \\
\%\end{array}$ & $\begin{array}{c}\mathrm{CaCO}_{3} \\
\%\end{array}$ & $\begin{array}{c}C E C \\
\mathrm{cmol}^{+} \mathrm{kg}^{-1}\end{array}$ & $\begin{array}{c}B D \\
g \mathrm{~cm}^{-3}\end{array}$ \\
\hline Mean & 7.98 & 2.42 & 1.41 & 26.60 & 38.08 & 1.31 \\
\hline Std Dev & 0.34 & 4.25 & 0.37 & 5.75 & 5.23 & 0.03 \\
\hline Min & 7.37 & 0.48 & 0.87 & 14.81 & 28.61 & 1.25 \\
\hline Max & 8.40 & 15.62 & 2.12 & 37.02 & 48.12 & 1.35 \\
\hline $\mathrm{SP}^{*}$ & $\begin{array}{c}\text { Sand } \\
\%\end{array}$ & $\begin{array}{c}\text { Silt } \\
\%\end{array}$ & $\begin{array}{c}\text { Clay } \\
\%\end{array}$ & $\begin{array}{c}\mathrm{Mg}^{++} \\
\mathrm{mg} \mathrm{kg}^{-1}\end{array}$ & $\begin{array}{c}\mathrm{K}^{+} \\
\mathrm{mg} \mathrm{kg}^{-1}\end{array}$ & $\begin{array}{c}\mathrm{Na}^{+} \\
\mathrm{mg} \mathrm{kg}^{-1}\end{array}$ \\
\hline Mean & 17.06 & 34.25 & 48.44 & 170.8 & 449.7 & 480.7 \\
\hline Std Dev & 7.08 & 4.52 & 7.63 & 45.2 & 78.2 & 151.8 \\
\hline Min & 5.00 & 24.00 & 30.00 & 100.1 & 328.5 & 303.6 \\
\hline Max & 31.00 & 39.00 & 60.00 & 234.3 & 664.7 & 943.0 \\
\hline
\end{tabular}

* Statistical Properties of Level EC: Electric conductivity, $\mathrm{CaCO}_{3}$ : Lime Content, OM: Organic Matter, CEC: Cation Exchange Capacity, BD: Bulk Density

\subsection{Soil sampling and analysis}

Soil samples were taken from 16 selected profiles to determine soil characteristics and especially carbon contents. The samples were air-dried, sieved to pass a 2-mm mesh, and stored in plastic bags for analysis of selected physical and chemical soil properties. Soil samples for particle size analysis were taken from each of the surface soils $(0-20 \mathrm{~cm})$.

The following soil analysis was carried out: $\mathrm{pH}$ measured in a 1:1 water soil ratio mixture according to Peech's method (1965); soluble salts according to Bower \& Wilcox (1965) method; $\mathrm{CaCO}_{3}$ by the Bernard calcimeter method (Vatan 1967); organic carbon according to Duchaufour (1970), cation exchange capacity (CEC) following the method of Chapman (1965). SOC, SIC, and TC in 16 profiles and each particle size fractions were measured by TOC analyzer (TOC - V-CSH Shimadzu (Kyoto-Japan)).

Particle size analysis was carried out by using the FAO-ISRIC system (1990) after the combination of the pipette Robinson and sieving. The fraction of bulk soils into five particle size fractions was conducted using sieves with the following sizes: 2000 , $425,150,106$, and $75 \mu \mathrm{m}$. These fractions were studied in the $20 \mathrm{~cm}$ surface soil from the studied area. For the quantification of soil organic carbon in each fraction, a subset of each particle size fraction was ground and determined according to Duchaufour (1970).

\subsection{Statistical methods}

For the statistical analysis, multiple linear tests were performed using analysis of variance (ANOVA) to determine whether there are any statistically significant differences between the means of the independent groups. Relationships among properties were studied using Pearson correlations. Soil chemical properties related to carbon content and pools were subjected to principal components analysis (PCA) to elucidate major variation patterns in terms of C pools. All statistical tests were performed with SPSS V26.0 and differences were considered significant when $\mathrm{P}<0.05$. 


\section{Results and Discussion}

\subsection{Organic, Inorganic, and Total carbon storage of the soils}

Storage of carbon (OC, IC, and TC) in the studied soil profiles were given in Figure 2. The total amount of SOC within soil profiles varied significantly among the selected areas $(\mathrm{P}<0.05)$. The SOC concentration were $7.60 \mathrm{~g} \mathrm{~kg}^{-1}$ in P1, $7.96 \mathrm{~g} \mathrm{~kg}^{-1}$ in $\mathrm{P} 2$, $11.55 \mathrm{~g} \mathrm{~kg}^{-1}$ in P3, $10.84 \mathrm{~g} \mathrm{~kg}^{-1}$ in $\mathrm{P} 4,8.31 \mathrm{~g} \mathrm{~kg}^{-1}$ in $\mathrm{P} 5,13.94 \mathrm{~g} \mathrm{~kg}^{-1}$ in P6, $9.22 \mathrm{~g} \mathrm{~kg}^{-1}$ in P7, $12.81 \mathrm{~g} \mathrm{~kg}^{-1}$ in P8, $12.39 \mathrm{~g} \mathrm{~kg}^{-1}$ in $\mathrm{P} 9,9.65 \mathrm{~g} \mathrm{~kg}^{-1}$ in $\mathrm{P} 10,8.45 \mathrm{~g} \mathrm{~kg}^{-1}$ in $\mathrm{P} 11,6.76 \mathrm{~g} \mathrm{~kg}^{-1}$ in $\mathrm{P} 12,9.93 \mathrm{~g} \mathrm{~kg}^{-1}$ in P13, $14.93 \mathrm{~g} \mathrm{~kg}^{-1}$ in P14, $6.13 \mathrm{~g} \mathrm{~kg}^{-1}$ in $\mathrm{P} 15$, and 7.89 $\mathrm{g} \mathrm{kg}^{-1}$ in P16, respectively. The SOC contents were low due to low precipitation and high temperature. Microbial activity in soil is highly affected by soil moisture and soil temperature, which has played an important role in $\mathrm{CO}_{2}$ emissions and $65-85 \%$ of this emission is due to the soil temperature (Büyükkılıç Yanardağ et al. 2004). In addition, the $\mathrm{CO}_{2}$ emission of the soils is very effective on the SOC and TN reserves. Furthermore, researchers indicated that the variability of soil C depends on soil texture, climate, vegetation, and land use and management, as well as differences in species and plant density (Yoo et al. 2006). Hontoria et al. (1999) stated that $45 \%$ of the variability in SOC in the Spanish peninsula can be explained by the annual precipitation, annual average temperature, and altitude parameters. In addition to the climate, the clay content and type of the soil in the region also affected the organic matter content. Also, the oxidation of organic matter was faster due to the calcareous soil character (Homann et al. 1995). It means that the presence of $\mathrm{CaCO}_{3}$ in the soil might also contribute to the stabilization of poorly crystallized Fe forms; this will contribute to SOC retention, likely regarding triple Fe-Ca-SOC complexes (Sowers et al. 2018).

The highest SOC content was found in P14 while, lowest in P15. The elevation and climate conditions of these soils were approximately similar, whereas SOC ratios were varied due to different soil management practices. Soil conditions in turn were most influenced especially in our region by the temperature and soil moisture regimes, although the mineralogical and biological regimes were also important (Buringh 1984).

The inorganic $\mathrm{C}$ concentration of the soils ranged; 3.93 in $\mathrm{P} 1,3.51$ in $\mathrm{P} 2,2.57$ in $\mathrm{P} 3,4.44$ in $\mathrm{P} 4,4.02$ in $\mathrm{P} 5,3.04$ in $\mathrm{P} 6,3.27$ in $\mathrm{P} 7,3.41$ in $\mathrm{P} 8,2.81$ in $\mathrm{P} 9,2.99$ in $\mathrm{P} 10,3.09$ in $\mathrm{P} 11,2.76$ in $\mathrm{P} 12,2.95$ in $\mathrm{P} 13,2.43$ in $\mathrm{P} 14,1.78$ in $\mathrm{P} 16$, and 4.07\% in $\mathrm{P} 16$, respectively. The plain soil had a high carbonate ratio, also pedogenic carbonate was predominant due to alkaline soils features. Khademi \& Mermut (1998) stated that if there is sufficient calcium in the soil solution, that is when the pH range is between 7.3 and 8.5, secondary carbonate accumulations start, and calcite is formed in the soil. Therefore, the inorganic carbon concentration of the soils was high.

The vertical distribution of SOC, SIC, TC are given in Figure 2. The results showed that SOC concentrations were decreased with increasing soil depth. However, SOC levels were distributed along with the whole soil profile. Batjes (1996) observed that the highest SOC concentration was accumulated in upper soil layers, but a large amount was also stored between 1 and 2-m depth. Furthermore, the storage of OC in soil depended on the balance between the addition of organic material (freshly dead plants and animal waste) mixing into the soil and losses of $\mathrm{C}$ through decomposition (Sollins et al. 1996). The degradation or decomposition of the organic matter here depends on its chemical composition and physical relationship with other soil components (Rovira et al. 2008).

Inorganic $\mathrm{C}$ concentration of the selected soils was high and increased with soil depth. Primary carbonates dissolve under arid to semi-humid climatic conditions and combine with the $\mathrm{CO}_{2}$ present in the soil solution and recrystallize and a significant amount of pedogenic (secondary) carbonates accumulate in the soil. In these soil horizons, carbonate accumulation is generally observed depending on the characteristics of the parent material and climatic conditions (Gocke et al. 2012).

\subsection{Soil particle sizes distribution}

The distribution of particle size fractions in the surface soil from study areas was given in Figure 3 . The soil fraction distribution in the size of $2000-850 \mu \mathrm{m}$ varied between $15.3 \%$ and $42.3 \%$, in the size of $850-250 \mu \mathrm{m}$ varied between $34.6 \%$ and $51.5 \%$, in the size of $250-150 \mu \mathrm{m}$ varied between 8.8 and $17.2 \%$, in the size of $150-75 \mu \mathrm{m}$ varied between 7.2 and $17.7 \%$, and $<75 \mu \mathrm{m}$ in size varied between 1.8 and $13.0 \%$. The results showed that the dominant size fractions were the largest (850-250 and 850-2000 $\mu \mathrm{m})$. Although the Harran Plain is Tethys Sea of sedimentary origin (Şengör et al. 1988), it can be easily observed that different land use has affected the soil particle size. Different soil management systems including cultivation and irrigation can modify soil particle distribution throughout the soil profile (Jaiyeoba 2003).

The high content of smectite in the soils and especially the transformation of palygorskite into this mineral enabled the plain soils to enrich with smectite. Soils dense as smectite are saturated with $\mathrm{Ca}^{++}$ions (Seyrek et al. 2005). When we evaluated the clay results (between 30 and $60 \%$ ), we thought that the reason for having the lowest percentage in $<75 \mu \mathrm{m}$ would be that the high $\mathrm{Ca}^{++}$ions in the soil bind the clay particles tightly together. 

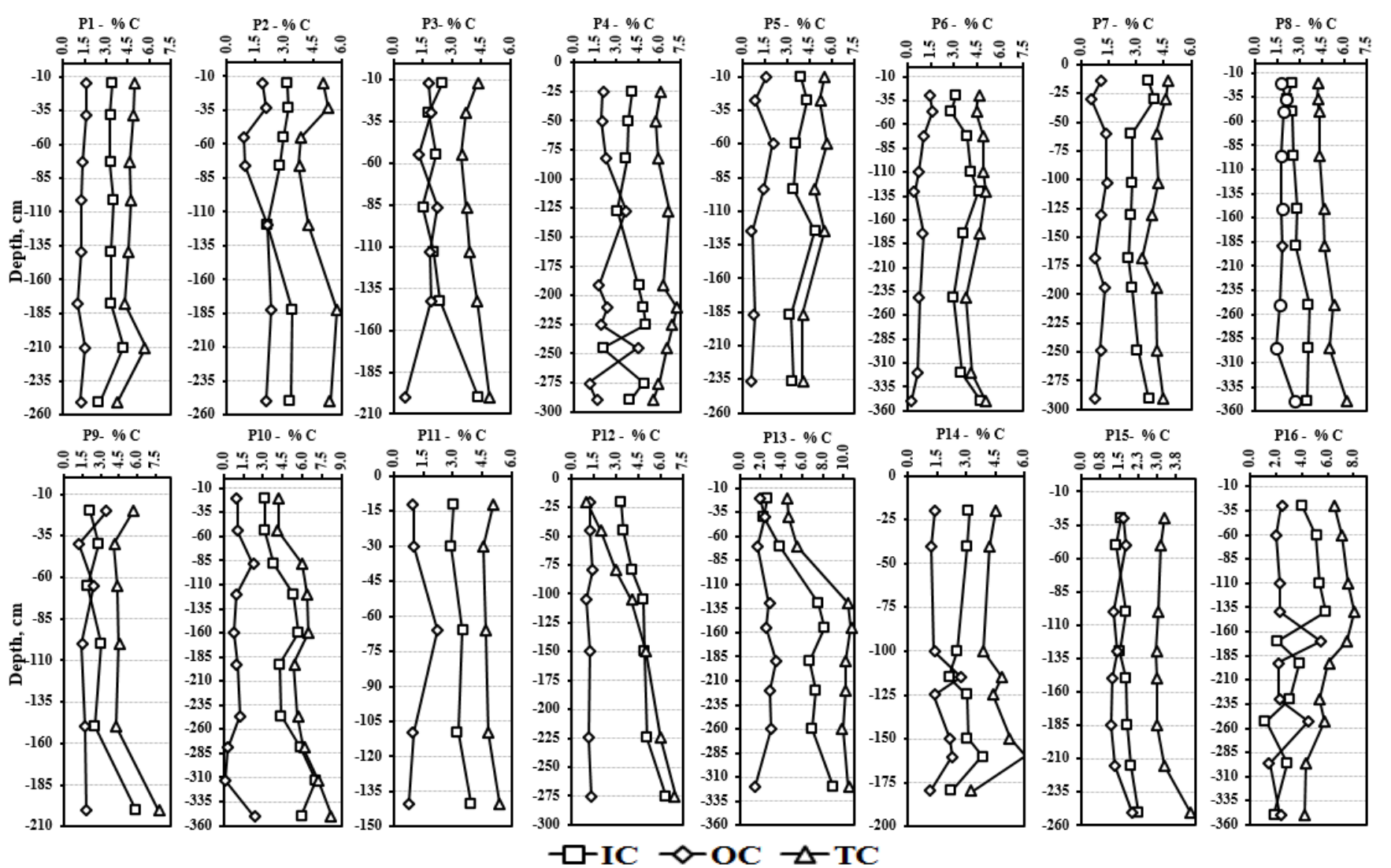

Figure 2- Carbon percentage concentration in 16 profiles (IC: Inorganic Carbon; OC: Organic Carbon; TC: Total Carbon, $\mathrm{n}=3$ )

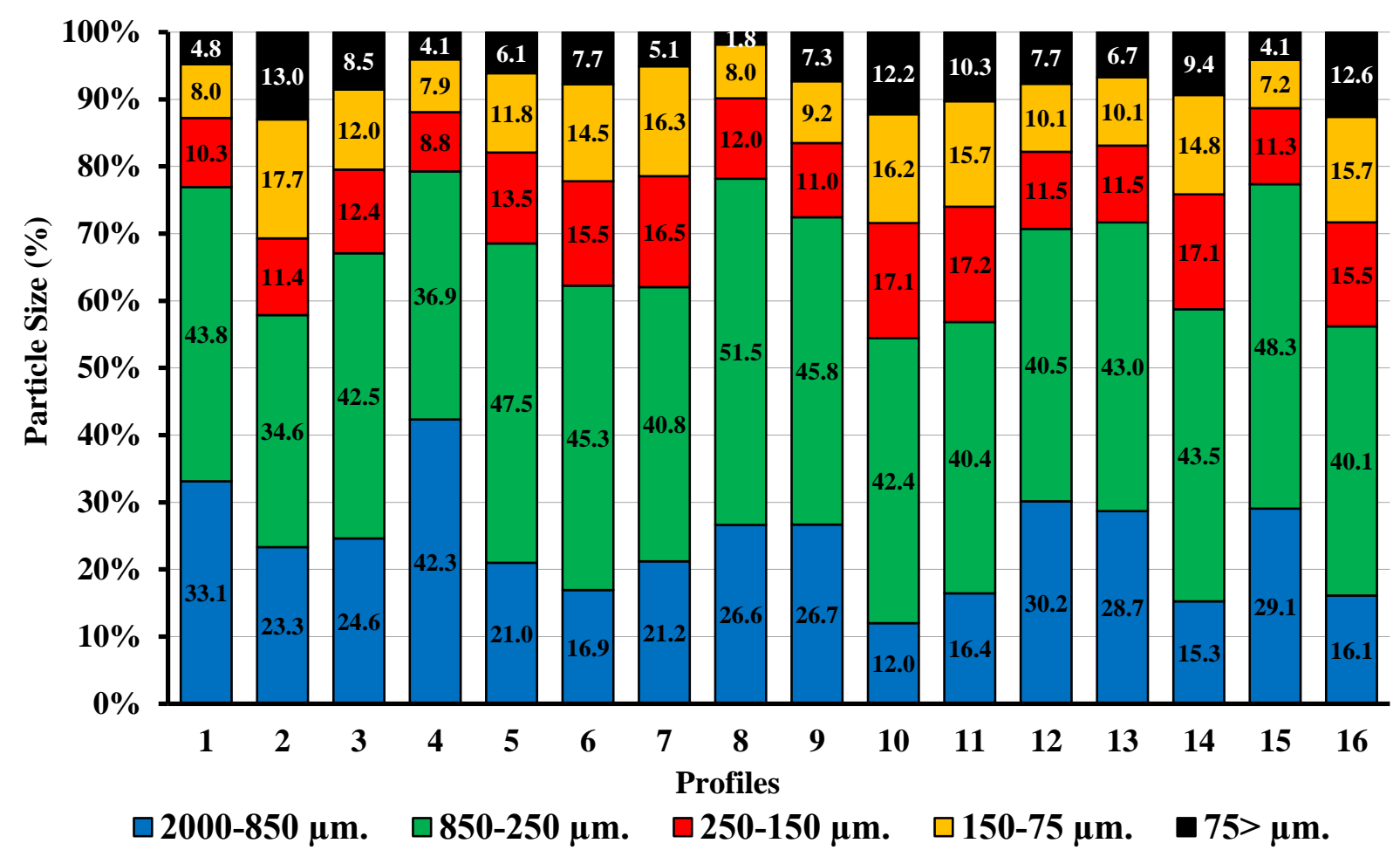

Figure 3- Distribution of particle size fractions in surface soil horizon

\subsection{Soil organic and inorganic carbon distribution in the different particle sizes}

Stable organic matter content at a particle size of $<50 \mu \mathrm{m}$ was significantly related to clay content, while coarse organic matter with a size of $>100 \mu \mathrm{m}$ was greatly affected by soil management systems (Quiroga et al. 1996). Distributions of SOC content in 
five particle size fractions in the surface horizon were given in Figure 4. Soil organic C content was increased with small size fractions. The highest SOC accumulation was observed between 250-150 um fractions.

Accoe et al. (2002) reported that SOC concentration was largest in small size fraction in a sandy loam textured soil. Carter et al. (2003) found that clay plus silt content (lower than 40\%) consisted of $60 \%$ of total organic carbon in 15 different sandy loam to heavy clay textured soil. Zhang et al. (2006) reported that the highest organic carbon accumulated in the clay size fraction in silty textured soil in Loess Plateau, Gansu- China. Chenu et al. (2000) found a significant relationship between organic matter and particle size fractions in varied humic loamy soils. Chen \& Chiu (2003), found a similar relationship in subalpine areas in central Taiwan. Contrarily, some researchers examined that the SOM level could reflect the intensity of soil use (Puget et al. 1995; Schulten et al. 1993).

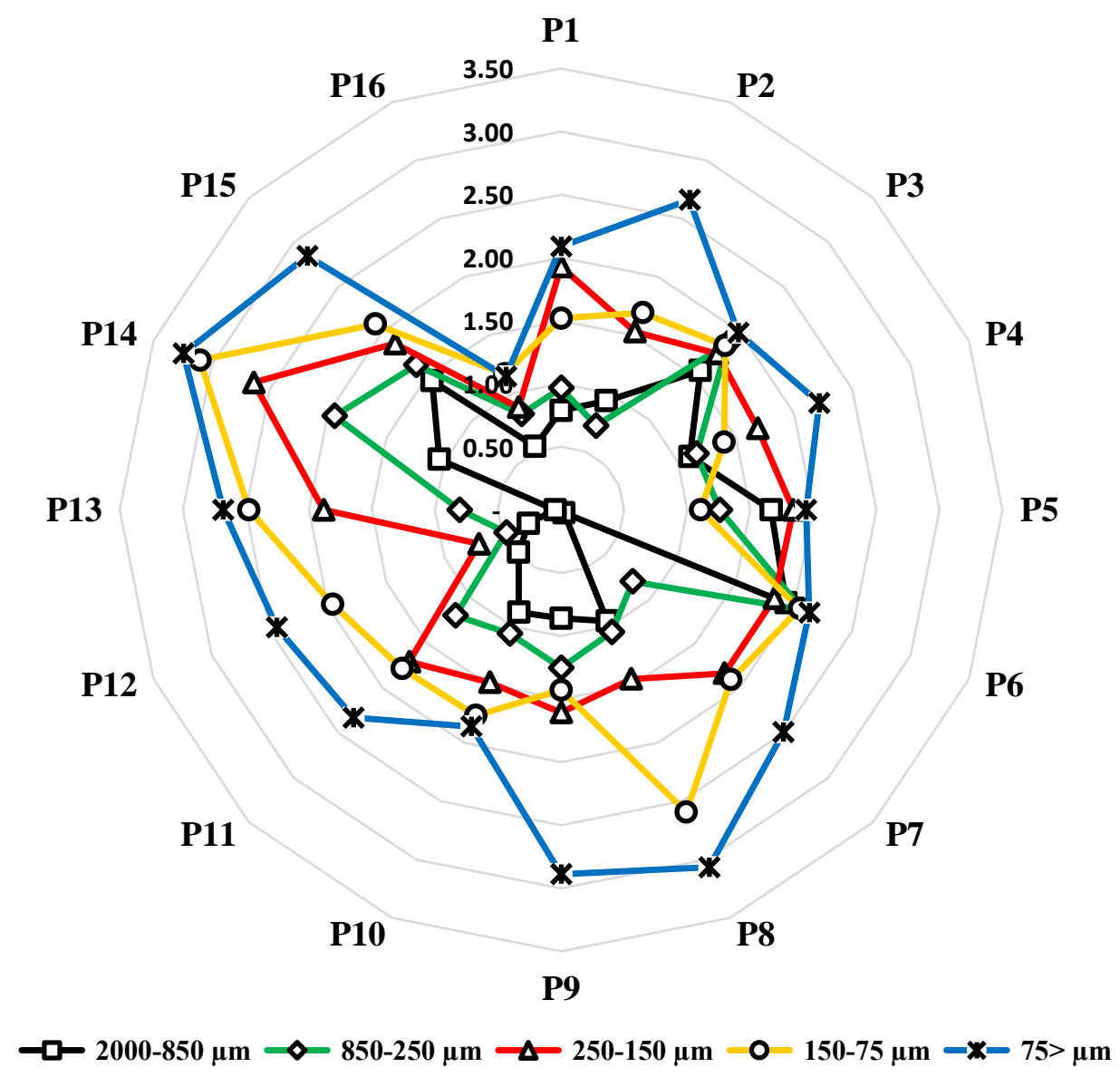

Figure 4- Distribution of soil organic carbon (\% SOC) in the five particle size fractions analyzed in the surface soil samples

In general, the quantity and nature of the clay affected the amount of $\mathrm{C}$ stabilized in the soil. Clay size fraction contributed most of the organic matter both for organic carbon and for nitrogen, with considerably smaller contributions from a silt-and sandsized fraction (Schmidt \& Kögel-Knabber 2002). The clay content of the soil is one of the most important factors affecting SOC accumulation. If the clay content is high, it may have higher SOC under similar climatic conditions and land use compared to soils with low clay content. Also, here the climate factor is the main determinant of the decomposition rate and time of $\mathrm{C}$ in the soil, thus directly influencing the amount of SOC (Milne 2008).

The SIC ranged between 1.29\% (in P11) and 6.49\% (in P16) in the particle sizes of $850-2000 \mu \mathrm{m}$, ranged between $0.48 \%$ (in P6) and 5.12\% (in P16) in the particle sizes of 250-850 $\mu \mathrm{m}$, ranged between $0.71 \%$ (in P12) and $4.90 \%$ (in P4) in the particle sizes of 150-250 $\mu \mathrm{m}$, ranged between $0.31 \%$ (in P10) and 5.39\% (in P4) in the particle sizes of 75-150 $\mu \mathrm{m}$, and ranged between $0.07 \%$ (in P10) and $4.62 \%$ (P1) in the particle sizes of $<75 \mu \mathrm{m}$, respectively (Figure 5). Contrary to the SOC, the SIC results were more recent and there were no major differences between the results. It can be said here that SIC is more stable than SOC and is more resistant to weathering. Also, Dong et al. (2017) reported that carbonates have different stabilities in different particle fractions, and this stability is more intense in clay than in sand and silt (Loeppert \& Suarez 1996). 


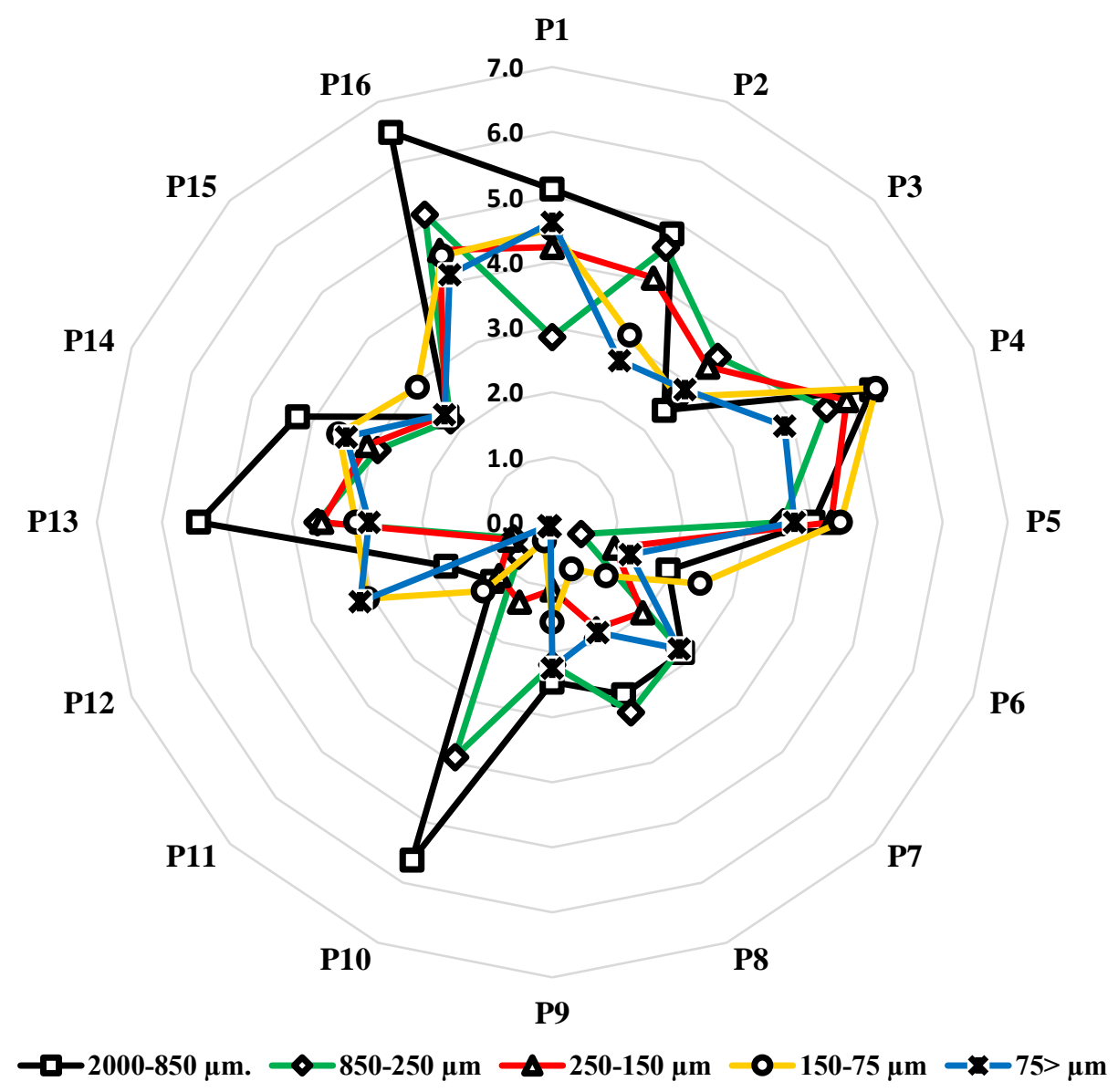

Figure 5- Distribution of soil inorganic carbon (\% SIC) in five particle size fractions of the surface soils

As a result of the correlation analysis between SOC and SIC in the 5 different particles fractions analysed on the 16 soil profiles, it was observed that these two parameters did not have a statistically significant relationship with each other $(\mathrm{p}>0.05)$ (Table 2). Dong et al. (2017) found a strong positive correlation between the SOC stock and SIC stock in selected 25 sites (3 in desert land, 9 in shrubland, and 13 in cropland) in soil from the semi-arid region in Yanqi Basin, China. With the breakdown of organic matter, there is an increase in the amount of $\mathrm{CO}_{2}$ in the environment, where $\mathrm{CO}_{2}$ combines with $\mathrm{H}_{2} \mathrm{O}$ to form $\mathrm{HCO}_{3}{ }^{-}$and in the next phase, $\mathrm{HCO}_{3}{ }^{-}$combines with $\mathrm{Ca}^{++}$ions found in large calcareous soils to form $\mathrm{CaCO}_{3}$ (Wang et al. 2015). Therefore, a positive relationship is expected between SOC and SIC. However, if the organic matter of these soils is very limited, this relationship is likely not to be significant.

Table 2- The correlation analysis between SOC and SIC in the 5 different soil particles fractions in 16 soil profiles

\begin{tabular}{|c|c|c|c|c|c|c|c|c|c|c|}
\hline & & $S I C$ & & & & $S O C$ & & & & \\
\hline & Particle size & $\begin{array}{l}850-250 \\
\mu \mathrm{m}\end{array}$ & $\begin{array}{l}250-150 \\
\mu \mathrm{m}\end{array}$ & $\begin{array}{l}150-75 \\
\mu \mathrm{m}\end{array}$ & $<75 \quad \mu \mathrm{m}$ & $\begin{array}{l}2000-850 \\
\mu \mathrm{m}\end{array}$ & $\begin{array}{l}850-250 \\
\mu \mathrm{m}\end{array}$ & $\begin{array}{l}250-150 \\
\mu \mathrm{m}\end{array}$ & $\begin{array}{l}150-75 \\
\mu \mathrm{m}\end{array}$ & $<75 \quad \mu \mathrm{m}$ \\
\hline \multirow[t]{5}{*}{ SIC } & $2000-850 \mu \mathrm{m}$ & $0.836^{* * *}$ & $0.718^{* * *}$ & 0.441 & 0.429 & -0.179 & -0.319 & -0.013 & -0.215 & -0.385 \\
\hline & $850-250 \mu \mathrm{m}$ & & $0.778^{* * *}$ & 0.341 & 0.419 & -0.039 & -0.238 & -0.031 & -0.260 & -0.298 \\
\hline & $250-150 \mu \mathrm{m}$ & & & $0.796^{* *}$ & $0.734^{* *}$ & 0.109 & -0.087 & 0.175 & -0.314 & -0.323 \\
\hline & $150-75 \mu \mathrm{m}$ & & & & $0.822^{* *}$ & 0.197 & 0.006 & 0.062 & -0.330 & -0.303 \\
\hline & $<75 \mu \mathrm{m}$ & & & & & -0.038 & -0.175 & 0.020 & -0.217 & -0.142 \\
\hline \multirow[t]{4}{*}{ SOC } & $2000-850 \mu \mathrm{m}$ & & & & & & $0.771^{* * *}$ & 0.304 & -0.101 & -0.082 \\
\hline & $850-250 \mu \mathrm{m}$ & & & & & & & $0.632^{* *}$ & 0.301 & 0.143 \\
\hline & $250-150 \mu \mathrm{m}$ & & & & & & & & 0.450 & 0.456 \\
\hline & $150-75 \mu \mathrm{m}$ & & & & & & & & & $0.714^{* *}$ \\
\hline
\end{tabular}

$* *$, Significant at $\mathrm{P}<0.01$. 
In addition, a similarity was observed in the relationship between SIC and SOC fraction distributions. Accordingly, when the fractions were close to each other, the significance increased, and no relationship was observed between the largest and smallest fractions. It can be said that this result is expected. Because it is quite common for particle sizes to show similar distribution between fractions.
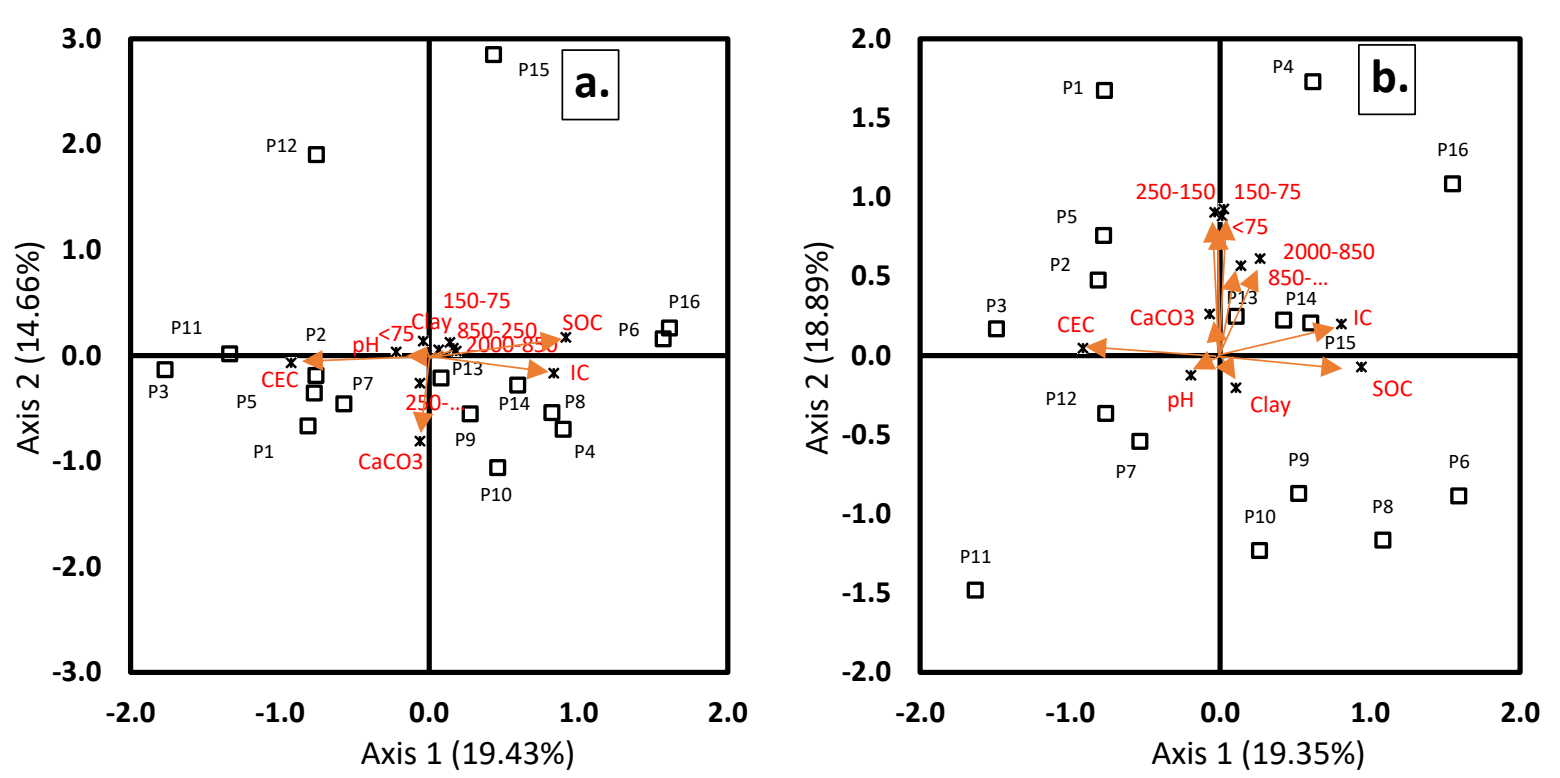

Figure 6- Biplot of principal component analysis (PCA) performed with SOC fractions (a) SIC fractions (b) and soil properties in 16 surface soil layers

The results of PCA analysis showed a distribution of $19.43 \%$ on axis 1 and $14.66 \%$ on axis 2 between SOC fractions and some soil properties in 16 profiles (Figure 6). In Axis 1, SOC, IC, fraction 2000-850 $\mu \mathrm{m}$ and fraction 850-250 $\mu \mathrm{m}$ showed a positive distribution, whereas $\mathrm{pH}$ and $\mathrm{CEC}$ showed a negative distribution. In Axis 2 , the $250-150 \mu \mathrm{m}$ fraction and $\mathrm{CaCO}_{3}$ showed a negative distribution, no remarkable distribution was observed in other parameters. According to the PCA analysis results, it showed a distribution of $19.35 \%$ on axis 1 and $18.89 \%$ on axis 2 between inorganic $\mathrm{C}$ fractions and some soil properties in 16 profiles. Similar to the SOC fraction in Axis 1, SOC, IC, fraction 2000-850 $\mu \mathrm{m}$ and fraction $850-250 \mu \mathrm{m}$ showed a positive distribution, whereas $\mathrm{pH}$ and $\mathrm{CEC}$ showed a negative distribution. In Axis 2, all IC fractions, IC, and $\mathrm{CaCO}_{3}$ showed a positive distribution, a slightly negative distribution was observed for $\mathrm{pH}, \mathrm{SOC}$, and Clay.

\section{Conclusions}

Semiarid climate conditions affected organic matter with the high temperature and deficiency of organic material affected the accumulation of organic carbon in the soil. Despite the high clay content of the soil, usually low organic matter and high lime contents depended on the structure was not develop the well. Particle-size distribution of soils was very important to understand their properties especially in terms of soil classification. Also, the features of clay minerals were another important factor for the distribution of particle sizes. In addition to soil, cultivation was of other importance for the accumulation of organic matter. The particle size distribution of surface soil samples was founded 850-250 > 2000-850 > 250-150 > 150-75>75 $\mu$ m. respectively. Distribution of SOC in particle size fractions were respectively $11 \%$ in $2000-850 \mu \mathrm{m} ., 15 \%$ in $850-250 \mu \mathrm{m}$., $21 \%$ in $250-150$ $\mu \mathrm{m} ., 23 \%$ in $150-75 \mu \mathrm{m}$. and $30 \%$ in $<75 \mu \mathrm{m}$. The particle size distribution influenced the quantity as well as the quality of soil organic matter. The high quantity of SOC accumulated in the below of $75 \mu \mathrm{m}$ fraction and it was concluded that the most important fraction in storing SOC was clay, followed by silt. When the vertical distribution of SOC accumulation was evaluated, it was found that SOC did not differ significantly between soil depths in any of the 16 evaluated soils, but increased strongly in the surface soil layer due to root density. However, IC distribution among soil layers varied, possibly due to different land uses. This study demonstrated that there was an inverse relation between SOC and particle size in Vertisol soils. Organic matter fractions differed according to particle size distribution and the prevailing soil management system. Stable organic matter content was significantly related to clay content and was strongly influenced by the type of soil management utilized.

\section{References}

Accoe F, Boeckx P, Van Cleemput O, Hofman, G X, Hui H Bin \& Guanxiong C (2002). Characterization of soil Organic Matter Fraction from Grassland and Cultivated Soils via C Content and $813 \mathrm{C}$ Signature. Rapid Commun Mass Spectrom 16: $2157-2164$. https://doi.org/10.1002/rcm.827

Batjes N H (1996). Total carbon and nitrogen in the soils of the world. European Journal of Soil Science 47: 151-163. https://doi.org/10.1111/j.1365-2389.1996.tb01386.x 
Bongiovanni M D \& Labartini J C (2006). Particulate organic matter, carbonhydrate, humic acid contents in soil macro- and microaggregates as affected by cultivation. Geoderma 133: 660-665. https://doi.org/10.1016/j.geoderma.2006.05.002

Bower C A \& Wilcox L V (1965). Soluble salts In C. A Black (Ed) Methods of Soils Analysis. Madison, Wisconsin, USA, American Society of Agronomy 2: 933-940

Büyükkılıç Yanardă̆ A, Faz Cano A, Mermut A, Yanardağ I H \& Gomez Garrido M (2020) Organic carbon fluxes using column leaching experiments in soil treated with pig slurry in SE Spain, Arid Land Research and Management, 34:2, 136-151. https://doi.org/10.1080/15324982.2019.1634158

Carter M R, Angers D A, Gregorich E G \& Bolinder M A (2003). Characterizing organic matter retention for surface soils in eastern Canada using density and particle size fractions. Canadian Journal of Soil Science 83: 11-23. https://doi.org/10.4141/s01-087

Chapman H D (1965). Cation Exchange Capacity. In: Black C A (ed) Methods of Soil Analysis American Society of Agronomy. Madison, Wisconsin, USA 2: 891-900. https://doi.org/10.2134/agronmonogr9.1

Chen J S \& Chiu C Y (2003). Characterization of soil organic matter in different particle-size fractions in humid subalpine soils by CP/MAS 13C NMR. Geoderma 117: 129-141. https://doi.org/10.1016/s0016-7061(03)00160-5

Chenu C, Le Bissonnais Y \& Arrouays D (2000). Organic matter influence on clay wettability and soil aggregate stability. Soil Science Society of America Journal 64: 1479-1486. https://doi.org/10.2136/sssaj2000.6441479x

Dalal R C \& Mayer R J (1986). Long-term trends in fertility of soils under continuous cultivation and cereal cropping in southern Queensland: IV Loss of organic carbon from different density fractions. Aust J Soil Res 24: 293-300. https://doi.org/10.1071/sr9860301

Duchaufour P H (1970) Precis de Pedologie. Masson Paris 481

FAO-ISRIC (1990). Guidelines for soil description $3^{\text {rd }}$ edit FAO Roma, 70

Figueiredo C C, Resck D V S \& Carneiro M A C (2010). Labile and stable fractions of soil organic matter under management systems and native cerrado. Revista Brasileira de Ciência do Solo 34(3): 907-916. https://doi.org/10.1590/s0100-06832010000300032

GDSHW - General Directorate of State Hydraulic Works (2003). Problems of drainage and salinity in the Harran plain Summary Report, the $15^{\text {th }}$ District Directorate of the State Hydraulic Works, Şanlıurfa, Turkey, 10 (in Turkish)

Gocke M, Pustovoytov K \& Kuzyakov Y (2012). Pedogenic carbonate formation: Recrystallization versus migration-Process rates and periods assessed by 14C labeling. Global Biogeochemical Cycle, Volume 26(1): 1-12. https://doi.org/10.1029/2010GB003871

Homann P S, Sollins P, Chappell H N \& Stangenberger A G (1995). Soil organic carbon in a mountainous, forested region: relation to site characteristics. Soil Science Society of America Journal 59: 1468-1475. https://doi.org/10.2136/sssaj1995.03615995005900050037x

Hontoria C, Rodriguez-Murillo J C \& Saa A (1999). Relationships between soil organic carbon and site characteristics in peninsular Spain. Soil Science Society of America Journal 63: 614-621. https://doi.org/10.2136/sssaj1999.03615995006300030026x

Khademi H \& Mermut A R (1998). Source of palygorskite in gypsiferous Aridisols and associated sediments from Central Iran. Clay Minerals 33: 561-578. https://doi.org/10.1180/claymin.1998.033.4.04

Li C, Qiu J, Frolking S, Xiao X, Salas W, Moore III B, Boles S, Huang Y \& Sass R (2002). Reduced methane emissions from large scale changes in water management of China's rice paddies during 1980-2000. Geophys Res Lett 29 (20). https://doi.org/10.1029/2002GL015370

Marinari S, Dell'Abate M T, Brunetti G \& Dais C (2010). Differences of stabilized organic carbon fraction and microbiological activity along Mediterranean Vertisols and Alfisols profiles. Geoderma 156: 379-388. https://doi.org/10.1016/j.geoderma.2010.03.007

Mermut A R, Amundson R \& Cerling T E (2000). The use of stable isotopes in studying carbonates dynamics in soils. In: Lal R, Kimble JM, Eswaran H \& Stewart BA, Editors, Global Climate Change and Pedogenic Carbonates, CRC Press, USA, pp. 65-85. https://doi.org/10.1201/9780203753187

Milne E (2008). Soils, Land-use and land-cover change, Natural resource management and policy and Climate change. wwweoearthorg/article/Soil_organic_carbon

Peech M (1965). Hidrogen-ion activity. In Black C A (Ed). Methods of Soil Analysis. American Society of Agronomy Madison, Wisconsin, USA 2: 914-916. https://doi.org/10.2134/agronmonogr9.2.c9

Puget P, Chenu C \& Balesdent J (1995). Total and young organic matter distributions in aggregates of silty cultivated soils. Eur J Soil Sci 46: 449-459. https://doi.org/10.1111/j.1365-2389.1995.tb01341.x

Quiroga A R, Buschiazzo D E \& Peinemann N (1996). Soil Organic Matter Particle Size Fractions in Soils of the Semiarid Argentinean Pampas. Soil Science 161 (2): 104-108. http://dx.doi.org/10.1097/00010694-199602000-00004

Rovira P, Kurz-Besson C, Coûteaux M M \& Vallejo V R (2008). Changes in litter properties during decomposition: a study by differential thermogravimetry and scanning calorimetry. Soil Biol Biochem 40: 172-185. https://doi.org/10.1016/j.soilbio.2007.07.021

Schmidt M W I \& Kögel-Knabber I (2002). Organic Matter in Particle Size Fraction from A and B Horizons of a Haplic Alfisol. European Journal of Soil Science 53: 383-391. https://doi.org/10.1046/j.1365-2389.2002.00460.x

Schulten H R, Leinweber P \& Sorge C (1993). Composition of organic matter in particle-size fractions of an agricultural soil. Journal of Soil Science 44: 611-691. https://doi.org/10.1111/j.1365-2389.1993.tb02332.x

Smith P (2004). Carbon sequestration in croplands: the potential in Europe and the global context. 20(3): 229-236. https://doi.org/10.1016/j.eja.2003.08.002

Soil Survey Staff (2006). Keys to Soil Taxonomy. $10^{\text {th }}$ ed. US Department of Agriculture-Natural Resources. Conservation Service. Washington, DC, USA

Sollins P, Homann P \& Caldwell B A (1996). Stabilization and destabilization of soil organic matter: mechanisms and controls. Geoderma 74: 65-105. https://doi.org/10.1016/s0016-7061(96)00036-5

Sowers T D, Stuckey, J W \& Sparks D L (2018). The synergistic effect of calcium on organic carbon sequestration to ferrihydrite Geochem. Trans., 19(2018), p. 4. https://doi.org/10.1186/s12932-018-0049-4

Tobiasova E, Debska B \& Banach-Szott M (2012). Influence of particle size distribution on soil on quantity and quality of soil organic matter. Acta Fytotechnica et. Zootechnica 1, Nitra, Slovaca Universitas Agriculturae Nitriaepp. 13-18. https://doi.org/10.2478/agri-2013-0001

Vatan M (1967). Manuel de Sédimentologie: Paris (Technip). ISBN 10: 271080073X

Yanardağ I H, Zornoza R, Cano A F, Yanardağ A B \& Mermut A R (2015). Evaluation of carbon and nitrogen dynamics in different soil types amended with pig slurry, pig manure and its biochar by chemical and thermogravimetric analysis. Biology and Fertility of Soils 51(2): 183-96. https://doi.org/10.1007/s00374-014-0962-3

Yesilnacar M I \& Güllüoğlu S M (2007). The effects of the largest irrigation of GAP project on groundwater quality, Șanlıurfa-Harran Plain, Turkey. FEB 16(2): 206-211. https://www.prt-parlar.de/download_feb_2016/ 
Yoo K, Amundson R, Heimsath A M \& Dietrich W E (2006). Spatial patterns of soil organic carbon on hillslopes: integrating geomorphic processes and the biological C cycle. Geoderma 130: 47-65. https://doi.org/10.1016/j.geoderma.2005.01.008

Zhang J H, Quine T A, Ni S J \& Ge F L (2006). Stocks and dynamics of SOC in relation to soil redistribution by water and tillage erosion. Change Biol. 12: 1834-1841. https://doi.org/10.1111/j.1365-2486.2006.01206.x

(C) 2022 by the author(s). Published by Ankara University, Faculty of Agriculture, Ankara, Turkey. This is an Open Access article distributed under the terms and conditions of the Creative Commons Attribution (CC BY) license (http://creativecommons.org/licenses/by/4.0/), which permits unrestricted use, distribution, and reproduction in any medium, provided the original work is properly cited. 